\title{
A székletkalprotektin meghatározásának szerepe a bélbetegségek diagnosztikájában és kezelésében
}

\author{
Iliás Ákos dr. ${ }^{1}$ - Rózsa Fióna Petra ${ }^{1}$ \\ Gönczi Lóránt dr. ${ }^{1}$ - Lovász Barbara Dorottya dr., ${ }^{1,3}$ \\ Kürti Zsuzsanna dr. ${ }^{1}$ - Lakatos Péter László dr. ${ }^{1,2}$ \\ 'Semmelweis Egyetem, Általános Orvostudományi Kar, I. Belgyógyászati Klinika, Budapest \\ ${ }^{2}$ McGill University, MUHC, Montreal General Hospital, Montreal, Kanada \\ ${ }^{3}$ Semmelweis Egyetem, Egészségtudományi Kar, Egészségfejlesztési és Klinikai Módszertani Intézet, \\ Egészségtudományi Klinikai Tanszék, Budapest
}

\begin{abstract}
Az elmúlt évtizedben a gastrointestinalis kórképek diagnosztikája sokat változott. Az endoszkópos és képalkotó módszerek mellett előtérbe kerültek a gyorsan elvégezhetô laboratóriumi diagnosztikus vizsgálatok is. Külön elônnnek számít, ha a vizsgálat könnyen ismételhető, így a krónikus betegségek követésére, az esetleges fellángolások időben történő felismerésére is alkalmas lehet. A székletkalprotektin meghatározása, mely más országokban már a mindennapi diagnosztika része, hazánkban is egyre több helyen hozzáférhető. Összefoglaló közleményünkben bemutatjuk a székletkalprotektin-vizsgálat szerepét és megbízhatóságát a gasztroenterológiai kórképekben, különös tekintettel a gyulladásos bélbetegségekre, a bélrendszeri fertőzésekre, az irritábilisbél-szindrómára és egyes gyermek gasztroenterológiai kórképekre. A különböző betegségekben és helyzetekben használatos határértékeknek és az ezekhez tartozó specificitásnak és szenzitivitásnak a bemutatásával szeretnénk segíteni a klinikai orvosokat a helyes döntéshozatalban. Orv Hetil. 2019; 160(9): 322-328.
\end{abstract}

Kulcsszavak: székletkalprotektin, colitis ulcerosa, Crohn-betegség, gastroenteritis, betegkövetés, relapsus

\section{The role of fecal calprotectin in the diagnosis and treatment of gastrointestinal diseases}

The diagnostics of gastrointestinal diseases have evolved significantly in the past few decades. Besides endoscopy and conventional imaging modalities, there is a growing interest for rapid point-of-care laboratory tests to help discriminate between diseases with similar clinical symptoms and/or help the follow-up of chronic conditions, predicting relapses. The fecal calprotectin testing is a routine diagnostic tool in many countries. It is also more and more accessible in Hungary as well. We aim to present a short review on the role and performance of fecal calprotectin test in the diagnosis and follow-up of gastrointestinal diseases, especially inflammatory bowel diseases, gastrointestinal infections, irritable bowel syndrome and pediatric conditions. By presenting the different cut-off values, sensitivity and specificity rates representative for each disease, we hope to further aid clinicians in decision-making regarding these conditions.

Keywords: fecal calprotectin, ulcerative colitis, Crohn's disease, gastrointestinal infections, follow-up, relapse

Iliás Á, Rózsa FP, Gönczi L, Lovász BD, Kürti Zs, Lakatos PL. [The role of fecal calprotectin in the diagnosis and treatment of gastrointestinal diseases]. Orv Hetil. 2019; 160(9): 322-328.

(Beérkezett: 2018. szeptember 2.; elfogadva: 2018. október 6.) 


\section{Rövidítések}

ANCA = (antineutrophil cytoplasmic antibody) antineutrophil citoplazmikus antitest; ASCA = anti-Saccharomyces cerevisiaeantitest; $\mathrm{CD}=$ (Crohn's disease $)$ Crohn-betegség; CRP $=\mathrm{C}$ reaktív fehérje; ECCO = (European Crohn's and Colitis Organisation) Európai Crohn és Colitis Társaság; ELISA = (enzyme-linked immunosorbent assay) enzimhez kapcsolt immunszorbensvizsgálat; $\mathrm{FC}=$ (fecal calprotectin $)$ székletkalprotektin; GFD = (gluten-free diet) gluténmentes diéta; IBD = (inflammatory bowel diseases) gyulladásos bélbetegségek; IBS = irritábilisbél-szindróma; $\mathrm{MRCP}=$ mágnesesrezonancia-cholangiopancreatographia; $\mathrm{MRE}=$ mágnesesrezonancia-enterográfia $;$ NEC $=$ nekrotizáló enterocolitis $;$ NSAID $=$ (nonsteroidal anti-inflammatory drug) nemszteroid gyulladásgátló; PPI = (proton pump inhibitor) protonpumpagátló; $\mathrm{UC}=($ ulcerative colitis) colitis ulcerosa

Az elmúlt évtizedben a gastrointestinalis kórképek diagnosztikája jelentős fejlődésen ment keresztül, és számos új vizsgálómódszer vált a mindennapi rutin részévé. Ezek nagy része - mint például az endoszkópos ultrahang, a mágnesesrezonancia-cholangiopancreatographia (MRCP), a mágnesesrezonancia-enterográfia (MRE) és a FibroScan - már Magyarországon is egyre több helyen érhető el, bár sok esetben még jelentős várakozással kell számolniuk az orvosoknak, betegeknek egyaránt. A fenti képalkotó módszerek korlátozott hozzáférhetősége miatt előtérbe kerültek a gyorsan elvégezhető laboratóriumi diagnosztikus vizsgálatok is. Az alapvető laboratóriumi és szerológiai módszerek azonban nem mindig kellöképpen specifikusak ahhoz, hogy a kezdetben gyakran hasonló klinikai képek közötti differenciálást segítsék. Külön előnynek számít, ha a vizsgálat gyorsan elkészül és többször ismételhető, így a krónikus betegségek követésére, az esetleges fellángolások időben történő felismerésére is alkalmas.

A székletkalprotektin (fecal calprotectin - FC) meghatározása, ami számos országban már a mindennapi diagnosztika része, hazánkban is egyre több helyen hozzáférhető, bár sajnos az egészségbiztosító még nem finanszírozza a vizsgálatot.

\section{A székletkalprotektin mérése}

A kalprotektin egy 36 kDa-os glikoprotein, amely számos sejtben megtalálható, de jelentős mennyiségben a neutrophil granulocytákban fordul elő. Antimikrobiális, immunmodulátor és antiproliferatív hatásokkal rendelkezik. Kalciummal és cinkkel komplexet képezve nem bomlik le a bélben, ellenáll a bakteriális proteolitikus bontásnak, így mennyisége a székletben meghatározható, és szobahőmérsékleten stabilan egy hétig kimutatható marad. Mivel a neutrophilek felszaporodása és jelenléte a gyulladásos állapotokban kifejezett, a kalprotektin mennyiségének kimutatása bizonyíthatja a neutrophilek jelenlétét és így a gyulladást a bélrendszerben [1-3]. A székletkalprotektin-mérés használatát a gyulladásos bélbetegségek gyulladásos aktivitásának meghatározására Røseth és munkacsoportja dolgozta ki elöször, majd a módszer széles körben elterjedtté vált [4]. Naismith és mtsai vizsgálatában a székletkalprotektin értéke nem mutatott néhány nap alatt szignifikáns ingadozást remisszióban lévő Crohn-betegek napról napra történő kalprotektinmeghatározása során [1]. Ugyanakkor javasolt a minta $+4{ }^{\circ} \mathrm{C}$-on tárolása a laboratóriumba való szállításig. A székletből kivont kalprotektin mérése általában enzimhez kapcsolt immunszorbensvizsgálattal (enzim-linked immunosorbent assay - ELISA) történik. $\mathrm{Az}$ analitika könnyítése és a mérés pontosítása céljából egyre modernebb eljárások kerültek kidolgozásra; a már hagyományosnak tekinthető ELISA-eljárás mellett terjed a kemilumineszcens immunszorbensvizsgálat, a lateralis tesztcsíkvizsgálat és a turbidimetriás immunszorbensvizsgálat alkalmazása is. Természetesen az egyes eljárások során kapott eredményeket normalizálni kell, hogy azok - lehetőség szerint - egymással összevetve is értékelhetők legyenek [3].

Mint minden mérési technikánál, figyelmet kell fordítani az esetleges álpozitív és álnegatív esetekre is. Az előbbiek lényegesen gyakrabban fordulnak elő, ezért a mérés hitelessége céljából ezekre fokozottan ügyelni kell. Álpozitivitást okozhat nemszteroid gyulladásgátlók (NSAID) vagy protonpumpagátló (PPI) gyógyszerek szedése, mellkasi gyulladásos kórképek és felső légúti fertőzés a felköhögött, majd lenyelt váladék miatt, gastrointestinalis vérzés, daganatos betegség, illetve a májcirrózis. A teszt elvégzése előtt tehát célszerü felhívni a beteg figyelmét a fenti gyógyszerekre, és lehetőség szerint leállítani a szedésüket $[2,3]$. Az álnegatív esetek előfordulása jóval ritkább, eddig csak coeliakiás betegek esetében számoltak be tévesen negatív teszteredményról [5].

\section{A székletkalprotektin használata különböző gasztroenterológiai kórképekben}

\section{Gyulladásos bélbetegségek}

A legnagyobb irodalma és jelentősége a FC meghatározásának a gyulladásos bélbetegségek (IBD) esetén van (1. táblázat) [6-14]. Az IBD-s betegek gondozása során nagy igény van olyan noninvazív, sugárterheléssel nem járó, gyakran ismételhető módszerekre, melyek segítséget nyújthatnak a relapsus korai felismerésében. Az egyre inkább elérhető biológiai kezelések és az IBD terápiás és betegkövetési stratégiájának elmúlt évtizedben látható fejlődése miatt nagy szerep jut az objektív, gyorsan elvégezhető biokémiai vizsgálatoknak is. A jelen terápiás konszenzusok által támogatott „treat to target” stratégia alapján a klinikai, endoszkópos és biokémiai (C-reaktív fehérje [CRP], FC) betegségaktivitás objektív monitorozása és a nyálkahártya-gyógyulás mint terápiás végpont a cél [15]. A biológiai terápiák alkalmazásával a nagy költségvonzat miatt egy nem kellően hatékony kezelés folytatása több szempontból is megkérdőjelezhető. Feltéte- 
1. táblázat |A gyulladásos bélbetegségek esetén vizsgált székletkalprotektinnel foglalkozó tanulmányok [6-14]

\begin{tabular}{|c|c|c|c|c|}
\hline Szerző, megjelenés & Bevont betegek száma & Vizsgált korreláció & Határérték szintje ( $\mu \mathrm{g} / \mathrm{g}$ ) & Szenzitivitás/specificitás (\%) \\
\hline von Roon et al. 2007 [6] & $\begin{array}{l}5983 \text { beteg } \\
\text { (metaanalízis) }\end{array}$ & $\begin{array}{l}\text { IBD - nem gyulladásos } \\
\text { eltérés }\end{array}$ & $>219 \mu \mathrm{g} / \mathrm{g}$ & $95 / 91$ \\
\hline van Rheenen et al. 2010 [7] & $\begin{array}{l}670 \text { beteg } \\
\text { (metaanalízis) }\end{array}$ & $\begin{array}{l}\text { IBD - nem gyulladásos } \\
\text { eltérés }\end{array}$ & $\begin{array}{l}\text { PhiCal: } 24 \mu \mathrm{g} / \mathrm{g} / 50 \mu \mathrm{g} / \mathrm{g} / \\
100 \mu \mathrm{g} / \mathrm{g} \\
\text { Roseth: } 150 \mu \mathrm{g} / \mathrm{g}\end{array}$ & $93 / 96$ \\
\hline Henderson et al. 2014 [8] & $\begin{array}{l}394 \text { IBD- és } 321 \text { nem } \\
\text { IBD-beteg gyermek } \\
\text { (metaanalízis) }\end{array}$ & $\begin{array}{l}\text { IBD - nem gyulladásos } \\
\text { eltérés }\end{array}$ & $\begin{array}{l}6 \text { vizsgálat: } 50 \mu \mathrm{g} / \mathrm{g} \\
2 \text { vizsgálat: } 100 \mu \mathrm{g} / \mathrm{g}\end{array}$ & $98 / 68$ \\
\hline Schoepfer et al. 2010 [9] & $122 \mathrm{CD}$ & $\begin{array}{l}\text { FC-szint - IBD endo- } \\
\text { szkópos aktivitás }\end{array}$ & $\begin{array}{l}>50 \mu \mathrm{g} / \mathrm{g} \\
>70 \mu \mathrm{g} / \mathrm{g}\end{array}$ & $\begin{array}{l}>50 \mu \mathrm{g} / \mathrm{g}: 89 / 58 \\
>70 \mu \mathrm{g} / \mathrm{g}: 89 / 72\end{array}$ \\
\hline Schoepfer et al. 2013 [10] & $\begin{array}{l}228 \text { UC, } 52 \\
\text { egészséges }\end{array}$ & $\begin{array}{l}\text { FC-szint - IBD endo- } \\
\text { szkópos aktivitás }\end{array}$ & $\begin{array}{l}>50 \mu \mathrm{g} / \mathrm{g} \\
>57 \mu \mathrm{g} / \mathrm{g}\end{array}$ & $\begin{array}{l}>50 \mu \mathrm{g} / \mathrm{g}: 92 / 86 \\
>57 \mu \mathrm{g} / \mathrm{g}: 91 / 90\end{array}$ \\
\hline Lin et al. $2014[11]$ & $\begin{array}{l}744 \text { UC és } 727 \text { CD } \\
\text { (metaanalízis, } 13 \\
\text { vizsgálat) }\end{array}$ & $\begin{array}{l}\text { FC-szint - endoszkópos } \\
\text { aktivitás }\end{array}$ & $\begin{array}{l}\text { Vizsgálatonként változó } \\
30-274 \mu \mathrm{g} / \mathrm{g}\end{array}$ & $\begin{array}{l}50 \mu \mathrm{g} / \mathrm{g}: 92 / 60 \\
100 \mu \mathrm{g} / \mathrm{g}: 84 / 66 \\
250 \mu \mathrm{g} / \mathrm{g}: 80 / 82\end{array}$ \\
\hline $\begin{array}{l}\text { García-Sánchez et al. } 2010 \\
\text { [12] }\end{array}$ & $66 \mathrm{CD}, 69 \mathrm{UC}$ & FC - IBD klinikai relapsus & $\begin{array}{l}\text { IBD: } 150 \mu \mathrm{g} / \mathrm{g} \\
\text { CD: } 200 \mu \mathrm{g} / \mathrm{g} \\
\text { UC: } 120 \mu \mathrm{g} / \mathrm{g}\end{array}$ & $\begin{array}{l}\text { IBD: } 75 / 68 \\
\text { CD: } 80 / 65 \\
\text { UC: } 81 / 63\end{array}$ \\
\hline Mao et al. 2012 [13] & $\begin{array}{l}354 \mathrm{CD}, 318 \mathrm{UC} \\
\text { (metaanalízis) }\end{array}$ & FC - IBD klinikai relapsus & $\begin{array}{l}\text { Vizsgálatonként változó, } \\
28-340 \mu \mathrm{g} / \mathrm{g}\end{array}$ & IBD: $78 / 73$ \\
\hline De Vos et al. 2013 [14] & $\begin{array}{l}\text { 87, infliximabbal } \\
\text { kezelt UC }\end{array}$ & FC - UC relapsus & $\begin{array}{l}<50 \mu \mathrm{g} / \mathrm{g}-\text { remisszió } \\
>300 \mu \mathrm{g} / \mathrm{g}-\text { relapsus }\end{array}$ & $\begin{array}{l}<50 \mu \mathrm{g} / \mathrm{g}: 83 / 83 \\
>300 \mu \mathrm{g} / \mathrm{g}: 93 / 58\end{array}$ \\
\hline
\end{tabular}

$\mathrm{CD}$ = Crohn-betegség; IBD = gyulladásos bélbetegség; UC = colitis ulcerosa

lezett klinikai relapsus vagy rutin betegkövetés során a túl gyakori endoszkópos vizsgálat a betegek életminőségét rontja, így az endoszkópia megismétlésébe gyakran nem egyeznek bele, vagy annak lehetőség szerinti kerülését, más metodikával történő kiváltását kérik. Egy friss multicentrikus vizsgálatban 22 ország 74 kórházában összesen 244 aktív Crohn-betegnél hasonlították össze a hagyományos klinikai betegkövetést és a szoros betegkövetést („tight control”), mely magában foglalta a rendszeres CRP- és FC-meghatározást is. Eredményeik alapján egyértelmúen kijelenthető, hogy a szoros betegkövetés és a biomarkerek rendszeres ellenőrzése szignifikánsan nagyobb arányban $(30,3 \%$ illetve $40,9 \%, \mathrm{p}=0,01)$ vezetett a kitűzött végpont (alacsony Crohn-betegségsúlyossági index $($ CDEIS<4) és mély fekélyek hiánya a tükrözés során) eléréséhez [16].

A nemzetközi irodalomban számos közlemény foglalkozik a pontos FC-határérték meghatározásával, mely alapján az aktív gyulladás jelenléte bizonyítható. Bár a FC-szintek igen széles tartományban mozognak, nemzetközileg elfogadott, hogy az $50 \mu \mathrm{g} / \mathrm{g}$ alatti érték nagy biztonsággal kizárja a jelentôs aktív gyulladást a bélrendszerben [2, 6]. Mindemellett több tanulmány igazolta, hogy a FC-szint emelkedésének mértéke szorosan korrelál a betegség endoszkópos aktivitásával [6] A legbiztatóbb eredmények colitis ulcerosában (UC) és kiterjedt bélérintettséggel járó CD esetében születtek. UC-ban a FC-szintek a klinikai tünetekkel is határozott korrelációt mutattak [17, 18]. A FC-szintek és a remisszió, illetve relapsus összefüggésére egy kvantitatív skálát is megpró- báltak felállítani. Több tanulmány alapján kijelenthető, hogy az $50 \mu \mathrm{g} / \mathrm{g}$ alatti FC-szint endoszkóposan inaktív, míg a $250 \mu \mathrm{g} / \mathrm{g}$ feletti FC biztosan valamilyen mértékben aktív betegséget jelez $[17,19]$. Egy 2014-es metaanalízis során 13 vizsgálat összesen 1471 betegének adatait elemezték (744 UC és 727 CD). $250 \mu \mathrm{g} / \mathrm{g}$ határérték esetén a FC összesített szenzitivitása és specificitása $0,80(0,76-0,84)$, illetve $0,82(0,77-0,86)$ volt az IBD-aktivitás tekintetében [11].

Arai japán munkacsoportja vékonybél-Crohn-betegeknél vizsgálta a FC összefüggését a komputertomográfiás leletekkel, valamint a ballonos enteroszkópia során látható elváltozásokkal. Eredményeik szerint a FC-szintek vékonybél-érintettség esetén is szignifikáns összefüggést mutattak az endoszkópos aktivitással, bár magasabb határértékek használatára volt szükség [20].

A FC meghatározása alkalmazható a terápia hatékonyságának követésére is; UC-ban a FC alkalmasnak bizonyult a nyálkahártya-gyógyulás előrejelzésére is [21]. A székletkalprotektin-szint mind az endoszkópos, mind a szövettani aktivitás megbízható jelzője volt colitis ulcerosában. A pontos határértékek meghatározásához ugyanakkor még további vizsgálatok szükségesek [22].

A vizsgálati eredményeket áttekintve tehát megállapítható, hogy a FC alkalmas a nyálkahártya-gyulladás mértékének megítélésére. Ennek megfelelően az Európai Crohn és Colitis Társaság (ECCO) legújabb iránymutatása is javasolja a CRP-szint mellett a FC meghatározását a betegség aktivitásának követésére, a relapsus és a remisszió monitorozására [23]. 


\section{A bél egyéb gyulladásos megbetegedései}

A kalprotektin az infektív eredetû bélgyulladások diagnosztikájában is fontos szerepet tölt be. Ismert, hogy a kalprotektinszintek szoros összefüggést mutatnak a bakteriális gastroenteritisszel. Szintén igazolt, hogy szintjének vizsgálatával következtetni lehet a Clostridium difficile-fertőzés fennállására, annak súlyosságára. A mérési szintek alapján a súlyos és a kevésbé súlyos Clostridiumfertőzöttek elkülöníthetők, így a FC-szintek elemzése alkalmassá válhatna a megfelelő antibiotikum kiválasztásának elősegítésére és terápiás követésre is [24, 25]. Érdekes eredmény, hogy az egyik 2016. évi kutatásban a FC-szintek szignifikáns korrelációt mutatnak a Clostridium egyik különösen virulens, toxintermelő változatával, a 027 -es ribotípus által okozott fertőzéssel. A 027 -es ribotípus sokszor mutat antibiotikumrezisztenciát, illetve az általa kiváltott fertőzések magasabb mortalitással járnak. A legtöbb rutinlaborban az ELISA használatával mutatják ki a toxintermelést, azonban ribotipizálást nem végeznek, így a FC-mérés ilyen irányú használata kiemelten fontos lehet a jövőben [26].

Bizonyított az is, hogy a kalprotektin a bakteriális és a nem fertőző hasmenések elkülönítésében igen megbízható marker, szemben a laktoferrinnel (vaskötő fehérje, a neutrophilek másodlagos granulumainak alkotórésze) és a guajakalapú okkultvérzés-teszttel. Bár a FC pontos eredményt adhat, hátránya viszont, hogy azokban a páciensekben, akikben amúgy is magas értéket mutathat (például IBD, májcirrózis, malignus betegségek), nem alkalmazható fertőzés igazolására [27]. A FC-szintek mérésére alapulnak olyan vizsgálatok is, melyekben a gyermekek akut gastroenteritisének etiológiai hátterét kívánják felkutatni. A FC-szintek mérésével a bakteriális és a virális eredet elkülöníthetôvé válna, mivel a bakteriális fertőzések esetén szignifikánsan magasabb szintek mérhetők, vélhetően a gyulladásos sejtek eltérő karaktere miatt. Csecsemők (1 hetes és 10 hónapos kor között) FC-szintje ugyan egészséges állapotban is emelkedett, de az említett eltérés itt is megjelent, így más referenciatartományok használatával a mérés esetükben is alkalmazhatónak bizonyulhat [28].

\section{Az irritábilisbél-szindróma differenciáldiagnosztikája}

A székletkalprotektin-szint meghatározásának egyik jelentős felhasználási területe a hasonló tüneteket okozó gastrointestinalis kórképek elkülönítése [29]. Az IBS miatt szakorvoshoz forduló betegek jelentős terhelést jelentenek az egészségügyi rendszer számára. A betegség kezdetén, később krónikus lefolyás esetén számos alkalommal nehéz a betegeket vagy az alapellátásban dolgozó orvosokat lebeszélni a vastagbéltüikrözés elvégzésérôl. Az IBD és az IBS elkülönítése sokszor nehéz feladat, jelentős hasi panaszok, széklethabitus-változás esetén negatív hasi ultrahang és kórjelző eltérést nem mutató la- borok mellett sem zárható ki biztonsággal az IBD diagnózisa. Sok esetben a panaszok visszatérése IBS-val éló beteg esetén ismételten felveti a vastagbéltükrözés szükségességét, bizonyítandó, hogy idóközben nem alakult ki esetlegesen IBD. Sokszor döntési nehézséget okoz, hogy IBD-s betegek körében szintén előfordulhat IBS-szerü tünet (Crohn-betegség esetén majdnem 60, UC-ban pedig majdnem 40\%-ban) [30]. A berni egyetemi munkacsoport a CRP, a fehérvérsejtszám, az IBDben jellemző antitestek és a székletvizsgálati markerek pontosságát vizsgálta, az endoszkópos leletek tükrében [31]. A székletből kimutatható markerek közül a laktoferrint és a kalprotektint (PHiCal-teszttel) vizsgálták, melyek mind önmagukban, mind az antineutrophil citoplazmikus antitest (ANCA) és az anti-Saccharomyces cerevisiae-antitest (ASCA) méréseivel kombinálva kiemelkedő eredményeket hoztak. A FC szenzitivitás/specificitás/pozitív/negatív prediktív értéke százalékban kifejezve 83/100/100/74 lett, ami a szerológiai meghatározással kombinálva javult $(91 \% / 100 \% / 100 \% / 93 \%)$.

Érdekes kérdés az IBS-hoz közel álló, de az elmúlt években lezajlott paradigmaváltásnak köszönhetően már attól teljesen elkülönülő mikroszkópos colitis. Von Arnim és mtsai mikroszkópos colitis- és IBS-betegek FC-értékeit vizsgálták. Eredményeik alapján aktív mikroszkópos colitis esetén szignifikánsan magasabb FCszinteket találtak [32].

\section{A kalprotektin használatának lehetőségei a gyermekgasztroenterológiában}

A noninvazív vizsgálatok különösen fontosak a gyermekgyógyászat területén. A FC meghatározása az előbbiekben említett fertőző gastroenteritisek elkülönítésén túl széles körben felhasználható. A neonatológiában kifejezetten fontos a gyors diagnózis a kezelés mielőbbi megkezdése szempontjából. Koraszülött csecsemókben az orális táplálás bevezetése sokszor okoz nehézségeket az intolerancia kialakulása miatt, melynek következtében súlyos gastrointestinalis szövődményeik is kialakulhatnak: hányás, hasmenés, hasi distensio, apnoe, bradycardia kialakulásával is számolni kell, míg a legsúlyosabb szövődmény, a nekrotizáló enterocolitis (NEC) akár életveszélyes is lehet. Bár etiológiája nem teljesen tisztázott, valószínúleg szerepe lehet benne az abnormális bakteriális kolonizációnak, ami a bélmucosa barrierjének elégtelensége miatt és az immunrendszer nem megfelelő válaszkészségének következményeként jön létre. Több tanulmány összefüggést mutatott ki a FC kiugróan magas szintje és a NEC előfordulása között. Bár azóta ezt az összefüggést nem mindegyik vizsgálat tudta igazolni, a FC mérése ígéretes prognosztikai marker lehet a jövőben bizonyos NEC-alcsoportok esetében [33].

A gyermekkori IBD noninvazív diagnosztikai lehetőségei között is fontos szerepet tölthet be a FC, mellyel számos kellemetlen beavatkozástól kímélhetnénk meg a gyermekeket. A vizsgálat megfelelő diagnosztikus pon- 
tosságához fontos hangsúlyozni, hogy az álpozitív esetek kiszürése érdekében egyéb diagnosztikus markerekkel javasolt kombinálni (CRP, székletvér, széklettenyésztés), hogy az esetlegesen felesleges eszközös vizsgálatok elvégzését elkerüljük.

Egyéb gyermekgasztroenterológiai kórképek felismerésében is segítségünkre lehet a FC-szintek mérése. A nemzetközi irodalom alapján a FC-meghatározás a coeliakiás gyermekek esetében a diagnózist és a követést is segítheti. A coeliakia diagnózisakor mért FC-szint határozottan magasabb értéket mutat, a szigorú gluténmentes diétát (gluten-free diet - GFD) tartó betegek és az egészséges kontrollok értékéhez képest. A GFD-csoportban, amennyiben a diéta következtében az endomysiumellenes antitestek jelenléte már nem mutatható ki, a FC-szint is csökkenő tendenciát mutat. Az értékek magasabbak a tipikus gastrointestinalis tüneteket mutató betegekéinél, mint a tünetmentes coeliakia esetében. Mindezek alapján a FC kiegészítheti a rutin-coeliakiadiagnosztikát és a betegség követését, amennyiben a diagnóziskor mérünk egy kiindulási értéket, melyhez a későbbiekben viszonyítunk az adott beteg esetében [34].

A bélrendszer bakteriális flórája, a mikrobiom kiemelkedő jelentőséggel bír az allergiás immunológiai kórképekben, amelyekben szintén emelkedett FC-érték mérhető. A bakteriális kolonizáció egyensúlyának felborulása által provokált gyulladásos folyamat a bélhám epithelkárosodásához vezet, aminek következtében fokozódik az áteresztő képessége, utat biztosítva az allergének bejutásához. Amennyiben ez elhúzódó folyamat, szerepe lehet többek között az atopiás dermatitis vagy egyéb, súlyos allergiás kórképek kialakulásában is.
A normális bélflóra és az immunsejtek rövid láncú zsírsavak segítségével hatással vannak egymásra; a bélrendszer mikrobiomja és a FC mint gyulladásos marker között így fontos kapcsolat áll fenn, ezt támasztja alá az is, hogy legalább egy hónapig tartó probiotikumkezelés után az emelkedett FC-szintek csökkennek. Ezen eredmények hatására a FC-szintek mérését több allergiás kórképben is sikerrel alkalmazták. Több esetben az emelkedett FC-szint jól korrelált az ételallergiákkal és az atopiás dermatitisszel gyermekekben. Ez utóbbi esetben alkalmas lehet a súlyosság megítélésére, sőt a legújabb eredmények szerint a betegség kialakulásának valószínúsége is előre megítélhető lenne a marker segítségével [35].

Szintén gyakori problémát jelent a gyermekkori colica, melynek hátterében ugyancsak felmerült a bélflóra összetételének változása (Klebsiella, anaerob Gram-negatív baktériumok, az Escherichia coli-és Lactobacillus-törzsek arányának eltolódása egészséges gyermekekhez képest). A FC közel kétszeres emelkedése volt megfigyelhető colicával küzdő gyermekekben, a neutrophilbeszűrődés jeleként, kontrollgyermekekkel összehasonlítva, mely a tünetek enyhülésével párhuzamosan csökkenő tendenciát mutatott $[36,37]$.

\section{Limitációk, gyakorlati megfontolások}

Minden diagnosztikus eljárás esetén figyelembe kell venni azonban bizonyos korlátozó körülményeket, melyek segítik a klinikust, hogy a tesztet megfelelően tudja értékelni. A FC esetében mindenképpen szem előtt kell tartanunk, hogy számos gyulladásos és nem gyulladásos kórképben emelkedett értéket mérhetünk, így ezek elkü-

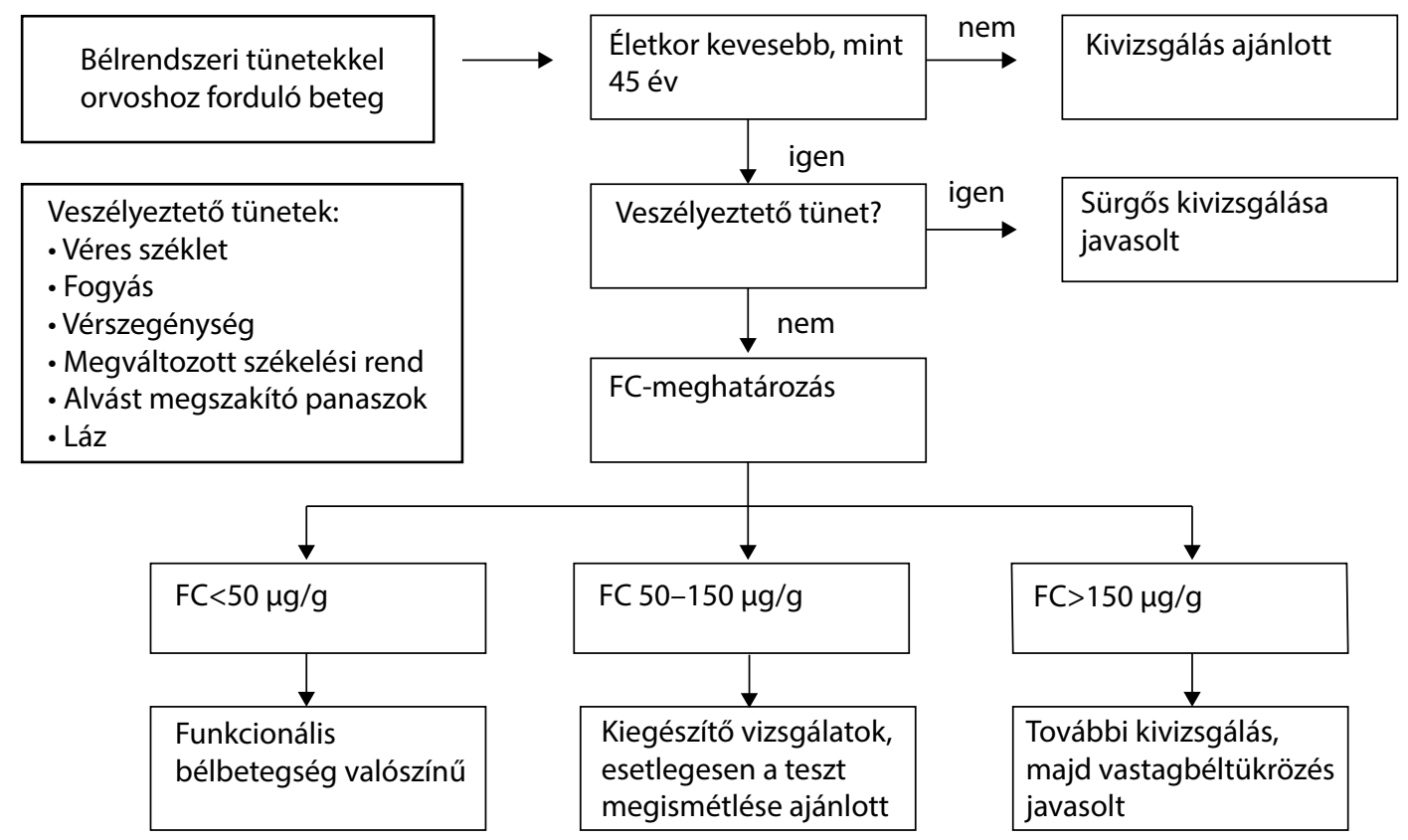

\begin{tabular}{l|l} 
1. ábra & $\begin{array}{l}\text { Egyszerúsített javaslat a székletkalprotektin használatára az alapellátásban } \\
\mathrm{FC}=\text { székletkalprotektin }\end{array}$
\end{tabular} 
lönítésére - például bakteriális enteritis kontra IBD nem alkalmas. Külön problémát jelent, hogy a gyomorbél rendszeri daganatok jelentős részében emelkedett FC-szintek tapasztalhatók, így például vastagbélpolipok jelenléte esetén is [38]. Korábban felmerült a FC felhasználása a vastagbéldaganatok szürése során is, de a legújabb vizsgálatok megkérdőjelezik a FC ilyen irányú felhasználását [39].

A helyes klinikai gyakorlat úgy foglalható össze, hogy amennyiben IBS-t vagy funkcionális kórképeket akarunk elkülöníteni egyéb bélrendszeri betegségektől, akkor a FC meghatározása megfelelő metodika; általában egy mérés elegendő ( 1 ábra). Az IBD és egyéb betegségek esetén mindig a klinikai képpel és a többi diagnosztikus eljárás eredményével együtt kell értékelni a kapott értéket. Amennyiben krónikus betegségek esetén használjuk a tesztet, érdemes mindig azonos meghatározást és labort alkalmazni, és az évek során kapott értékeket egymással összehasonlítva következtetni a mért FC-szint jelentésére.

\section{Következtetés}

Összefoglalásként kiemelnénk, hogy a neutrophil granulocytákból származó kalprotektin fehérje megbízható noninvazív marker, melynek segítségével a gyulladás mértéke felmérhetô. Megjelenik a nyálban, a cerebrospinalis és synovialis folyadékban, a vérben, illetve a székletben is. Mivel ellenáll az emésztőenzimeknek, a székletben éri el a legmagasabb koncentrációját: a vérben található koncentrációjának mintegy hatszorosát. Értéke emelkedett a gyulladásos betegségekben, bakteriális infekciók fennállásakor, illetve a daganatos folyamatok miatt is (például vastagbéldaganatban). Szintén magasabb szinteket találunk allergia, májcirrózis és NSAID, PPI szedése esetén.

A vizsgálatot hazánkban a felnőttgyógyászatban a társadalombiztosító nem finanszírozza, de már egyre több laborban hozzáférhető.

$\mathrm{Az}$ indikáció és a fenti megfontolások figyelembevételével történő székletkalprotektin-meghatározás a betegek számára nem megterhelő vizsgálat, mely mind a tápcsatornai betegségek differenciáldiagnosztikájában, mind a betegek követésében a kezelőorvosok segítségére lehet a megfelelő terápia megválasztásában $[5,40]$.

Anyagi támogatás: A szerzők a közlemény megírásával kapcsolatban anyagi támogatásban nem részesültek.

Szerzői munkamegosztás: A kézirat megírásában minden szerző részt vett, és a cikk végleges változatát valamenynyien elolvasták és jóváhagyták.

Érdekeltségek: A szerzóknek nincsenek érdekeltségeik.

\section{Irodalom}

[1] Naismith GD, Smith LA, Barry SJ, et al. A prospective singlecentre evaluation of the intra-individual variability of faecal calprotectin in quiescent Crohn's disease. Aliment Pharmacol Ther. 2013; 37: 613-621.

[2] Waugh N, Cummins E, Royle P, et al. Faecal calprotectin testing for differentiating amongst inflammatory and non-inflammatory bowel diseases: systematic review and economic evaluation. Health Technol Assess. 2013; 17: 1-211.

[3] Caviglia GP, Ribaldone DG, Rosso C, et al. Fecal calprotectin: beyond intestinal organic diseases. Panminerva Med. 2018; 60: 29-34.

[4] Røseth AG, Schmidt PN, Fagerhol MK. Correlation between faecal excretion of indium-111-labelled granulocytes and calprotectin, a granulocyte marker protein, in patients with inflammatory bowel disease. Scand J Gastroenterol. 1999; 34: 50-54.

[5] Carroccio A, Iacono G, Cottone M, et al. Diagnostic accuracy of fecal calprotectin assay in distinguishing organic causes of chronic diarrhea from irritable bowel syndrome: a prospective study in adults and children. Clin Chem. 2003; 49: 861-867.

[6] von Roon A, Karamountzos L, Purkayastha S, et al. Diagnostic precision of fecal calprotectin for inflammatory bowel disease and colorectal malignancy. Am J Gastroenterol. 2007; 102: 803813.

[7] van Rheenen FP, Van de Vijver E, Fidler V. Faecal calprotectin for screening of patients with suspected inflammatory bowel disease: diagnostic meta-analysis. BMJ 2010; 341: c3369.

[8] Henderson P, Anderson NH, Wilson DC. The diagnostic accuracy of fecal calprotectin during the investigation of suspected pediatric inflammatory bowel disease: a systematic review and meta-analysis. Am J Gastroenterol. 2014; 109: 637-645.

[9] Schoepfer AM, Beglinger C, Straumann A, et al. Fecal calprotectin correlates more closely with the Simple Endoscopic Score for Crohn's disease (SES-CD) than CRP, blood leukocytes, and the CDAI. Am J Gastroenterol. 2010; 105: 162-169.

[10] Schoepfer AM, Beglinger C, Straumann A, et al. Fecal calprotectin more accurately reflects endoscopic activity of ulcerative colitis than the Lichtiger Index, C-reactive protein, platelets, hemoglobin, and blood leukocytes. Inflamm Bowel Dis. 2013; 19: 332-341.

[11] Lin J, Chen J, Zuo J, et al. Meta-analysis: fecal calprotectin for assessment of inflammatory bowel disease activity. Inflamm Bowel Dis. 2014; 20: 1407-1415.

[12] García-Sánchez V, Iglesias-Flores E, González R, et al. Does fecal calprotectin predict relapse in patients with Crohn's disease and ulcerative colitis? J Crohns Colitis 2010; 4:144-152.

[13] Mao R, Xiao YL, Gao X, et al. Fecal calprotectin in predicting relapse of inflammatory bowel diseases: a meta-analysis of prospective studies. Inflamm Bowel Dis. 2012; 18: 1894-1899.

[14] De Vos M, Louis EJ, Jahnsen J, et al. Consecutive fecal calprotectin measurements to predict relapse in patients with ulcerative colitis receiving infliximab maintenance therapy. Inflamm Bowel Dis. 2013; 19: 2111-2117.

[15] Peyrin-Biroulet L, Sandborn W, Sands BE, et al. Selecting therapeutic targets in inflammatory bowel disease (STRIDE): determining therapeutic goals for treat-to-target. Am J Gastroenterol. 2015; 110: 1324-1338.

[16] Colombel JF, Panaccione R, Bossuyt P, et al. Effect of tight control management on Crohn's disease (CALM): a multicentre, randomised, controlled phase 3 trial. Lancet 2018; 390: 27792789 .

[17] D'Haens G, Ferrante M, Vermeire S, et al. Fecal calprotectin is a surrogate marker for endoscopic lesions in inflammatory bowel disease. Inflamm Bowel Dis. 2012; 18: 2218-2224. 
[18] Josué V, Chaparro M, Gisbert JP. Accuracy of fecal calprotectin for the prediction of endoscopic activity in patients with inflammatory bowel disease. Dig Liver Dis. 2018; 50: 353-359.

[19] Falvey J, Gearry R, Day A. Fecal calprotectin does not predict endoscopic remission in inflammatory bowel disease. Inflamm Bowel Dis. 2013; 19: 80-81.

[20] Arai T, Takeuchi K, Miyamura M, et al. Level of fecal calprotectin correlates with severity of small bowel Crohn's disease, measured by balloon-assisted enteroscopy and computed tomography enterography. Clin Gastroenterol Hepatol. 2017; 15: 56-62.

[21] Kristensen V, Røseth A, Ahmad T, et al. Fecal calprotectin: a reliable predictor of mucosal healing after treatment for active ulcerative colitis. Gastroenterol Res Pract. 2017; 2017: 2098293.

[22] Mak WY, Buisson A, Andersen M, J et al. Fecal calprotectin in assessing endoscopic and histological remission in patients with ulcerative colitis. Dig Dis Sci. 2018; 63:1294-1301.

[23] European Crohn's and Colitis Organisation. Published ECCO Guidelines. Vienna, 2017. Available from: https://www.eccoibd.eu/publications/ecco-guidelines-science/published-eccoguidelines.html

[24] Kim J, Kim H, Oh HJ, et al. Fecal calprotectin level reflects the severity of Clostridium difficile infection. Ann Lab Med. 2017; 37: $53-57$.

[25] Gallo A, Vallone C, Sabatelli L, et al. Fecal calprotectin in management of Clostridium difficile infection: a longitudinal study. Scand J Gastroenterol. 2018; 53: 567-572.

[26] Peretz A, Tkhawkho L, Pastukh N, et al. Correlation between fecal calprotectin levels, disease severity and the hypervirulent ribotype 027 strain in patients with Clostridium difficile infection. BMC Infect Dis. 2016; 16: 309.

[27] Shastri Y, Bergis D, Povse N, et al. Prospective multicenter study evaluating fecal calprotectin in adult acute bacterial diarrhea. Am J Med. 2008; 121: 1099-1106.

[28] Duman M, Gencpinar P, Biçmen M, et al. Fecal calprotectin: can be used to distinguish between bacterial and viral gastroenteritis in children? Am J Emerg Med. 2015; 33: 1436-1439.

[29] D'Incà R, Dal Pont E, Di Leo V, al. Calprotectin and lactoferrin in the assessment of intestinal inflammation and organic disease. Int J Colorectal Dis. 2007; 22: 429-437.

[30] Fu Y, Wang L, Xie C, et al. Comparison of non-invasive biomarkers faecal BAFF, calprotectin and FOBT in discriminating IBS from IBD and evaluation of intestinal inflammation. Sci Rep. 2017; 7: 2669.

[31] Schoepfer A, Trummler M, Seeholzer P, et al. Discriminating IBD from IBS: comparison of the test performance of fecal markers, blood leukocytes, CRP, and IBD antibodies. Inflamm Bowel Dis. 2008; 14: 32-39.

[32] Von Arnim U, Wex T, Ganzert C, et al. Fecal calprotectin: a marker for clinical differentiation of microscopic colitis and irritable bowel syndrome. Clin Exp Gastroenterol. 2016; 9: 97103.

[33] Moussa R, Khashana A, Kamel N, et al. Fecal calprotectin levels in preterm infants with and without feeding intolerance. J Pediatr. 2016; 92: 486-492.

[34] Balamtekin N, Baysoy G, Uslu N, et al. Fecal calprotectin concentration is increased in children with celiac disease: relation with histopathological findings. Turk J Gastroenterol. 2012; 23: 503-508.

[35] Seo SC, Ahn HS, Ri S, et al. Elevated fecal calprotectin levels are associated with severity of atopic dermatitis in children. Asian Pac J Allergy Immunol. 2018; 36: 82-87.

[36] Savino F, Cordisco L, Tarasco V, et al. Molecular identification of coliform bacteria from colicky breastfed infants. Acta Paediatr. 2009; 98: 1582-1588.

[37] Fatheree NY, Liu Y, Taylor CM, et al. Lactobacillus renteri for infants with colic: a double-blind, placebo-controlled, randomized clinical trial. J Pediatr. 2017; 191: 170-178.e2.

[38] Tibble J, Sigthorsson G, Foster R, et al. Faecal calprotectin and faecal occult blood tests in the diagnosis of colorectal carcinoma and adenoma. Gut 2001; 49: 402-408.

[39] Ye X, Huai J, Ding J. Diagnostic accuracy of fecal calprotectin for screening patients with colorectal cancer: a meta-analysis. Turk J Gastroenterol 2018; 29: 397-405.

[40] Bonnin Tomàs A, Vila Vidal M, Rosell Camps A. Fecal calprotectin as a biomarker to distinguish between organic and functional gastrointestinal disease. Rev Esp Enferm Dig. 2007; 99: 689693.

(Iliás Ákos dr., Budapest, Korányi Sándor u. 2/a, 1083 e-mail: driliasakos@gmail.com)

\section{"Etiam innocentes cogit mentiri dolor." (Publilius Syrius) (Még az ártatlant is megtanítja hazudni a fájdalom.)}

A cikk a Creative Commons Attribution 4.0 International License (https://creativecommons.org/licenses/by/4.0/) feltételei szerint publikált Open Access közlemény, melynek szellemében a cikk bármilyen médiumban szabadon felhasználható, megosztható és újraközölhetö, feltéve, hogy az eredeti szerző és a közlés helye, illetve a CC License linkje és az esetlegesen végrehajtott módositások feltüntetésre kerülnek. (SID_1) 